\title{
A tribute to Woldstedt (1952): Problems of terrace formation
}

\author{
James Rose $^{1,2}$, David R. Bridgland ${ }^{3}$, and Rob Westaway ${ }^{4, \boldsymbol{t}}$ \\ ${ }^{1}$ Department of Geography, Royal Holloway, University of London, Egham, Surrey, TW20 0EX, UK \\ ${ }^{2}$ British Geological Survey, Keyworth, Nottingham, NG12 5GG, UK \\ ${ }^{3}$ Department of Geography, University of Durham, Durham, DH1 3LE, UK \\ ${ }^{4}$ James Watt School of Engineering, University of Glasgow, James Watt (South) Building, Glasgow, G12 8QQ, UK \\ $\boldsymbol{t}_{\text {deceased }}$
}

Correspondence: James Rose (jimrose@clara.co.uk, j.rose@ rhul.ac.uk)

Relevant dates: $\quad$ Received: 7 June 2021 - Revised: 7 July 2021 - Accepted: 30 October 2021 Published: 17 December 2021

How to cite:

Rose, J., Bridgland, D. R., and Westaway, R.: A tribute to Woldstedt (1952): Problems of terrace formation, E\&G Quaternary Sci. J., 70, 217-220, https://doi.org/10.5194/egqsj-70-217-2021, 2021.

Special issue statement. This article is part of a special issue published on the occasion of the 70th anniversary of $E \& G$ Quaternary Science Journal (EGQSJ). The special issue celebrates the journal's notable contribution to Quaternary research by revisiting selected milestone articles published in the long history of EGQSJ. The German Quaternary Association (DEUQUA) presents translations of the originals and critical appraisals of their impact in tandem anniversary issues of DEUQUASP and EGQSJ, respectively.

Original article: https://doi.org/10.3285/eg.02.1.04

Translation: https://doi.org/10.5194/deuquasp-3$35-2021$

\section{Scientific background}

River terraces are important landforms. For society, they provide safe spaces for human habitation in proximity to a water resource; a landscape suitable for agriculture, transport and an infinite range of human requirements including groundwater; minerals; and aggregates. For science, these landforms and sediments provide a proxy for understanding river development in response to a range of climatic, sea-level and tectonic forces, as well as an archive for the records of landscape evolution, climate change, geodiversity, biodiversity and human occupance.
River terraces have two components: (i) the first component is an erosional surface called a strath. This is a landform that has long challenged geomorphologists because of the difficulties of producing a relatively level erosional plain when the potential energy of a river means that it has a natural tendency to erode vertically. This landform did not attract Paul Woldstedt's attention. (ii) The second component is a depositional landform, with an upper surface, known as a tread, and a slope separating the tread from other treads or the river channel, known as a bluff (British English) or riser (American English). These features are composed predominantly of sand, sand and gravel, and coarser material up to boulder size. Treads are relatively level but complex surfaces reflecting deposition within a river channel, deposition on the surface beyond the river channel and intermittent erosional events.

Typically, river terraces form what is often known as a cross-valley staircase of treads and bluffs, which may be made of either erosional or depositional surfaces or an almost infinite combination of both (cut-and-fill terraces). The formation of these terrace staircases is a topic that has attracted much attention, and many substantive papers have presented models to explain the patterns of erosion and aggradation (see below and references therein). Explanations involve uplift or submergence of the land and steepening or flattening of the land, both of which determine accommodation 
space for river deposition. Explanations also involve increase or decrease in sediment supply to the river, increase or decrease in the size of sediment supplied to the river, increase or decrease in river discharge, and particularly variations in high-magnitude flood events. It is little wonder that the subject has attracted substantial research and numerous publications in geology and geomorphology (Pazzaglia, 2013). Likewise, the presence of plant, animal and human remains within the sediments, along with an understanding of the factors that cause changes in the patterns of erosion and aggradation, means that terraces have also attracted the attention of palaeobiologists, archaeologists, climate-change scientists and Quaternary scientists.

At about the same time as Woldstedt's EGQSJ article was published, Zeuner (1952) summarised the main factors considered to be responsible for the formation of river terraces as follows: tectonic processes: sea-level change (thalassostatic terraces), climate changes in the form of sediment supply from a glacier, and variations in river discharge and sediment supply due to changes in climate and vegetation cover. Zeuner also recognised that the climatic origin of river terraces meant that they had the potential to provide a chronology for the Quaternary with the recognition and ordering of cold and warm periods. Paul Woldstedt had much respect for Frederick Zeuner, and it was within this framework that he developed his concepts.

\section{The formation of river terraces - characteristics and processes of formation according to Paul Woldstedt}

Woldstedt addressed the issue of river terraces by describing critical evidence for each of the formational scenarios and ended by presenting a scheme for terrace formation that integrates much of that evidence (Fig. 1). This scheme is perceptive, widely applicable and relevant to present concepts. Nevertheless, he noted that "Die im Vorstehenden gemachten Ausführungen bieten mehr Problemstellungen als Lösungen" [The explanations given above offer more problems than solutions] (Woldstedt, 1952, p. 44) and looked forward to the results of future investigations.

The effects of climatic processes on terrace formation are examined with evidence from the Saale and Elbe regions of central Germany and the Thames and Somme regions of southern England and northern France. Within the framework of the climatic model, Woldstedt considered that the primary process for the formation of these terraces is deposition of glacial and periglacial deposits during periods of cold climate and erosion during periods of "passive" warm climates and that these activities are tuned to the glacial-interglacial cycles as identified by Penck and Brückner (1909). However, he was critically aware that this model is challenged because terrace deposits may be composed of both cold and warm climate sediments. He was aware that some of the warm climate proxies included in the terrace deposits may not be in situ, but he rejected derivation as a general explanation and stressed the fact that a single terrace may contain evidence of different climates and that this material may be located at either the bottom or the top of the sediment body. Furthermore he noted that the relative position of these warm and cold sediment units may vary within a catchment and between river systems.

In order to explain this apparent anomaly, he identified the importance of sea level as a factor able to control the process of deposition or erosion at the lower part of river systems. According to this proposition, a rise in sea level would cause a reduction in the gradient of the channel in the lower part of a river, resulting in aggradation during interglacials. At the same time, incision would characterise the development of the upper reaches. In contrast, during glacials when sea level was low, incision would take place in the lower parts of catchments due to a steepening of the channel and aggradation would take place in the upper reaches due to increased sediment supply from periglacial and glacial processes. The extent of incision or aggradation through a catchment would depend upon the duration of the period of low sea level, gradient of the seabed in the exposed offshore zone and the duration of the depositional processes in the upper reaches. $\mathrm{He}$ also took care to note that the tuning between the rise in sea level and sedimentation would not coincide directly with the climate at the river mouth, as there would be a lag in sea-level rise due to the time taken for global ice masses to melt. Likewise, he stressed that the rate of sea-level rise would determine the pattern of sedimentation. A rapid rise would submerge the river mouth, and sediment would be located offshore, so that aggradation in the lower part of the river valley would be limited. The effects of these processes are summarised in Fig. 1, which is based on Fig. 2 of Woldstedt (1952), and it is evident that the processes of terrace development are very complex.

Woldstedt examined the issue of a solely tectonic origin for river terraces by reference to work done on the river Rhine, in which it had been proposed that deposition took place during periods of tectonic stability and incision occurred during periods of uplift that tilted the river towards the sea. He rejected this model because it failed to take into account the consequences of sea-level change and variations in sediment supply caused by glaciation and periglaciation. Nevertheless, he fully acknowledged that tectonic activity would be a factor responsible for terrace formation but that it needed to be validated by available evidence.

In addition to the mechanisms described above, Woldstedt responded to the proposal that terraces would develop due to the blockage of a river by an ice sheet. He examined this issue by reference to the river Weser in northern Germany, in which it was recognised that an ice dam had created a proglacial lake in the river valley upstream of the Scandinavian ice margin. Paul Woldstedt reasoned that this process would have resulted in the formation of a delta in the 


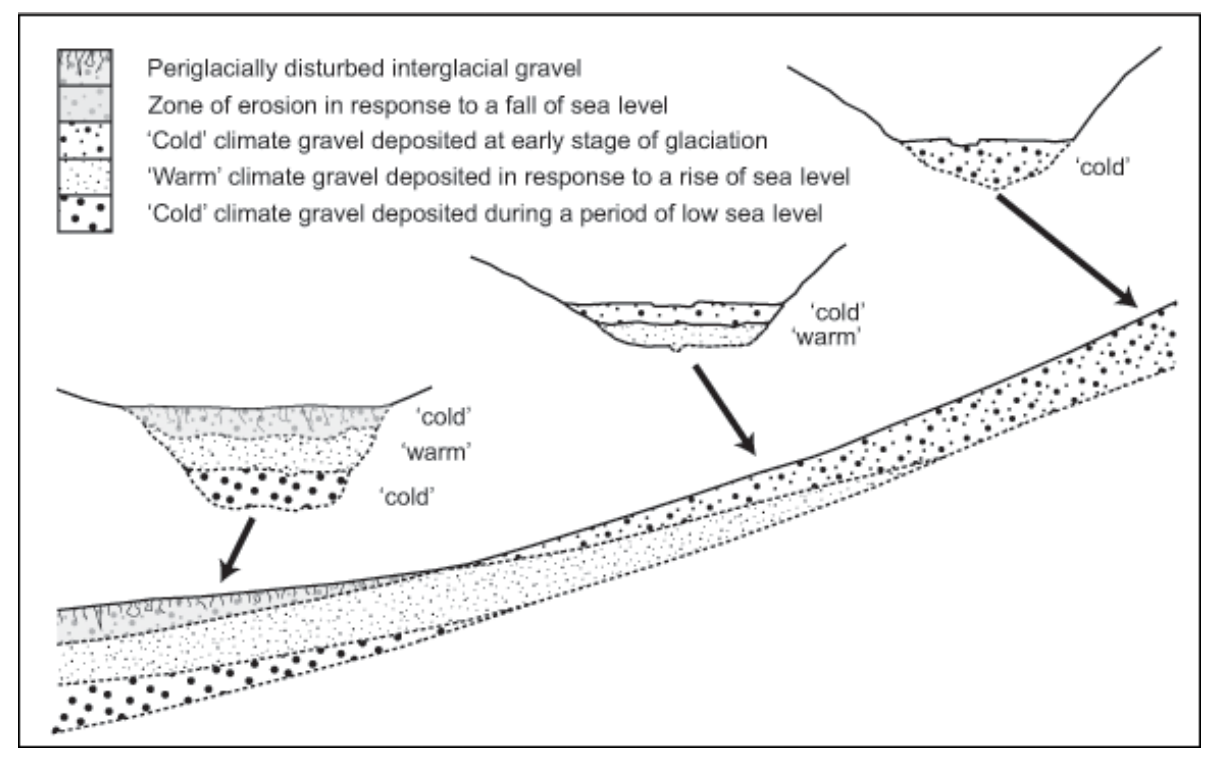

Figure 1. Redrawn version of Fig. 2 from Woldstedt (1952) with the addition of representative cross sections.

proglacial lake and that this would be of restricted extent, not significantly affecting existing river terraces. He also noted that it would be capable of being differentiated from terraces by the presence of deltaic topset and foreset sedimentary structures, supporting his case with a figure showing a stratigraphic succession indicating river gravels, overlain by lake sediments, and capped by glacial and glaciofluvial deposits. His proposition has been vindicated and expanded by recent work of Winsemann et al. (2015). Furthermore he noted that the subsequent deposition downstream of the ice dam would have a different lithological composition from material deposited in terraces in the upper part of the catchment.

\section{The significance of Paul Woldstedt's contribution to the understanding of river terrace formation}

The recognition that the pattern of terrace development varies along the length of a river catchment was a fundamental contribution to geomorphology and Quaternary science (Fig. 1). This premise requires that any study of river terraces must be aware of the potentially infinite variety of erosional/depositional permutations and approach the subject with this constraint in mind. The following section considers how science has responded to this requirement.

\section{The formation of river terraces - a perspective from 2021}

Since Woldstedt published his work in 1952, there has been an explosion of data collection and research on the topic of river terrace formation, illustrated best by the activities of the International Geoscience Programme: IGCP 449 "Global Correlation of Late Cenozoic Fluvial Deposits" and
IGCP 518 "Fluvial Sequences as Evidence for Landscape and Climatic Evolution in the Late Cenozoic" (Bridgland and Westaway, 2014).

Nearly all of the new findings have been based on developments in technology and the application of knowledge from associated sciences. For instance methods of dating terrace deposits (Schaller et al., 2016) now include ${ }^{14} \mathrm{C}$ of organic material held within the terrace deposits; thermo-luminescence, optically stimulated luminescence and infrared-stimulated luminescence (TL, OSL and IRSL) of quartz and feldspar sand grains comprising terrace deposits; amino acid racemisation ratio (AAR) determinations of specific organic materials held in the sediments; and U-series ratio determinations of calcrete precipitates in caves and sediments or organic material from within the terrace. Additionally dating can be achieved by palaeomagnetism and cosmogenic nuclides produced in situ measured from depth profiles through the terraces and cosmogenic surface exposure dating of boulders at the terrace surface. Likewise stratigraphic links to datable materials such as basalt lavas can provide a fine age resolution using $\mathrm{Ar} / \mathrm{Ar}$ or $\mathrm{U}-\mathrm{Pb}$ ratio determinations. Geochronometrically constrained biostratigraphic assemblages, especially mammal assemblage zones (MAZ), have also been used to date the age of terrace deposits (Schreve et al., 2007).

The ability to assign an age to a terrace with some degree of confidence has meant that it is possible to further evaluate factors that have determined terrace formation. The most significant outcome has been the establishment of a relationship between river terrace formation and climate change expressed in the form of Milankovitch orbital forcing. In cool temperate latitudes, such as those considered by Woldstedt, three patterns of river development can be identified 
for the late Cenozoic (Rose, 2010; Bridgland and Westaway, 2014). Small-scale precession variations $(22 \mathrm{kyr})$, prior to ca. 2.6 Ma, provided limited power for surface processes, and rivers transported fine-grained sediments over low-relief terrain, with limited terrace development. Between 2.6 and $0.9 \mathrm{Ma}$ when obliquity forcing (44 kyr) was dominant, coldclimate processes introduced power into river systems that then began to shape the landscape and transport well-sorted, coarser-grained sediment with extensive but often poorly defined terraces. In contrast, over the past $0.9 \mathrm{Myr}$, eccentricity forcing on a $100 \mathrm{kyr}$ timescale generated long periods of cold-climate processes and of river sedimentation and incision tuned to $100 \mathrm{kyr}$ cycles. However, over this period, lowland glaciation could greatly complicate the products of river activity (as Woldstedt clearly recognised).

Tied into this approach, the application of stream power calculations explains the focus of incision, transport and deposition throughout a catchment-long profile (Pazzaglia, 2013).

Stream power $\Omega=\rho g Q S$,

where $\rho$ is the density of the fluid, $g$ is the acceleration due to gravity, $Q$ is discharge and $S$ is slope.

High power is generated by high (snowmelt) runoff, leading to the erosion, transport and deposition of readily available cold-climate-derived sediments. Low power is constrained by relatively low (vegetation-controlled) discharge and the concentration of sediment sources to within the river channel. Thus, in cold climates, incision is focussed on the upper parts of catchments and sedimentation takes place in lower reaches. Alternatively in climates permitting an effective vegetation cover, (limited) aggradation is focussed on the upper part of catchments, and channel incision is characteristic of lower reaches. In turn, the critically important finding that in areas of responsive mobile lower crust, incision in the upper parts of river systems and deposition in adjacent subsiding basins result, through positive feedback, in progressive, periodic land uplift and associated subsidence in the upper and lower parts of the catchments respectively (Bridgland and Westaway, 2014). It is under these conditions that the classic, incised terrace staircases developed.

With these building blocks of river terrace development in place, it is possible to provide some general explanations. In addition to the climatic controls outlined above, tectonic processes can increase or decrease stream power by altering gradients within a channel. The role of lags within the system, whereby one relationship (such as river aggradation or incision) can be maintained temporarily out of phase with a contemporary forcing factor, can explain variations within system models. Specifically, stream power distribution in cool temperate catchments can mean that aggradation can take place at a coastline during cold-climate periods of low sea level. Alternatively, if climatically forced processes operate for a relatively short duration, then sedimentation may not extend throughout a catchment and incision may occur in relation to an equivalent fall of sea level.

Financial support. The article processing charge was funded by the Quaternary scientific community, as represented by the host institution of EGQSJ, the German Quaternary Association (DEUQUA).

Review statement. This paper was edited by Markus Fuchs and reviewed by one anonymous referee.

\section{References}

Bridgland, D. R. and Westaway, R.: Quaternary fluvial archives and landscape evolution: a global synthesis, Proc. Geol. Assoc., 125, 600-629, 2014.

Pazzaglia, F. J.: 9.22 Fluvial Terraces, in: Treatise on Geomorphology, edited by: Shroder, J. F., Academic Press, London, UK, 379-412, 2013.

Penck, A. and Brückner, E.: Die Alpen im Eiszeitalter (3 vols), Tauchnitz, Leipzig, Germany, 1189 pp., 1909.

Rose, J.: The Quaternary of the British Isles: factors forcing environmental change, J. Quaternary Sci., 25, 399-418, 2010.

Schaller, M., Ehlers, T. A., Stor, T., Torrent, J., Lobato, L., Christl, M., and Vockenhuber, C.: Timing of European fluvial terrace formation and incision rates constrained by cosmogenic nuclide dating, Earth Planet. Sc. Lett., 451, 221-231, 2016.

Schreve, D. C., Keen, D. H., Limondin-Lozouet, N., Auguste, P., Santistebane, J. I., Ubilla, M., Matoshko, A., Bridgland, D. R., and Westaway, R.: Progress in faunal correlation of Late Cenozoic fluvial sequences 2000-4: the report of the IGCP 449 biostratigraphy subgroup, Quaternary Sci. Rev., 26, 2970-2995, 2007.

Winsemann, J., Lang, J., Roskosch, J., Polom, U., Böhner, U., Brandes, C., Glotzbach, C., and Frechen, M.: Terrace styles and timing of terrace formation in the Weser and Leine valleys, northern Germany: response of a fluvial system to climate change and glaciation, Quaternary Sci. Revi., 123, 31-57, 2015.

Woldstedt, P.: Probleme der Terrassenbildung, E\&G Quaternary Sci. J., 2, 36-44, https://doi.org/10.3285/eg.02.1.04, 1952.

Zeuner, F. E.: Dating the Past, Methuen, London, UK, 1952. 